\title{
Potential use of triticale in diets for rainbow trout: effects of dietary levels and incidence of cooking
}

\author{
EF Gomes 1, SJ Kaushik 2*
}

1 Instituto de Ciências Biomédicas Abel Salazar, Universidade do Porto, Portugal;

${ }^{2}$ INRA, Laboratoire de Nutrition des Poissons, 64310 Saint-Pée-sur-Nivelle, France

(Received 11 April 1989; accepted 2 June 1989)

\begin{abstract}
Summary - It is recognized that an increase in digestible energy (DE) can improve the growth performance and protein retention efficiency in rainbow trout. Growth and digestibility trials were conducted to evaluate possible incorporation of triticale (Clercal, a soft wheat $x$ rye hybrid, hexaploid variety) as a potential source of $D E$ for rainbow trout. Four diets were formulated with graded levels of native triticale $(0-30 \%$ of dry matter) and 2 others with pre-cooked triticale at 20 and $30 \%$ of DM. All diets were isoproteic (crude protein: $43 \% \mathrm{DM}$ ) and isoenergetic (gross energy: $20 \mathrm{~kJ} / \mathrm{g} \mathrm{DM}$ ). Digestibility of dry matter, starch and energy was affected by both level and nature of triticale. Cooking (15 min, $110^{\circ} \mathrm{C}$ ) improved nutrient digestibilities of diets containing triticale. Growth performance and nutrient retention efficiencies were higher in fish fed diets containing precooked triticale than in those receiving equivalent amounts of native triticale. Triticale appears to hold potential value as an ingredient in trout diets provided some pretreatment of the cereal is made to improve starch digestibility.
\end{abstract}

\section{triticale / rainbow trout / digestibility / starch / energy}

Résumé - Possibilité d'incorporation du triticale dans le régiment alimentaire de la truite arc-en-ciel. I/ est bien établi qu'une augmentation de l'apport en énergie digestible (sous forme de lipides ou de glucides digestibles) permet d'améliorer les performances zootechniques chez la truite arc-en-ciel. Nous avons réalisé des essais afin d'évaluer la possibilité d'incorporation du triticale (variété hexaploïde, Clercal, hybride blé tendre $x$ seigle) en tant que source d'énergie digestible dans les aliments destinés à la truite arc-en-ciel. Six aliments expérimentaux ont été formulés ayant des taux variables de triticale cru $(0,10,20$ et $30 \%$ de la matière sèche de la ration) ou du triticale précuit (20 et $30 \%$ MS). Des essais zootechniques ont été réalisés à une température de 15 à $17{ }^{\circ} \mathrm{C}$ sur une durée de 8 semaines. Des mesures des coefficients d'utilisation digestive apparente (CUDa) ont également été effectuées. Nos résultats montrent que l'incorporation du triticale non-traité diminue les CUDa de la matière sèche, de l'amidon et de l'énergie. La cuisson $\left(110^{\circ} \mathrm{C}, 5 \mathrm{~min}\right)$ permet d'améliorer de façon significative les valeurs des CUDa. Cette amélioration se traduit également par un meilleur indice de consommation et par une augmentation des coefficients d'utilisation protéique et énergétique chez les truites recevant des régimes contenant du triticale précuit. En conclusion, il apparaît que le triticale précuit peut être incorporé jusqu'à un taux de $30 \%$ de la ration destinée aux truites.

triticale / digestibilité / truite arc-en-ciel / énergie / glucides

\footnotetext{
" Correspondence and reprints
} 


\section{INTRODUCTION}

Commercial diets for domestic animals usually contain a high level of cereals, which represent the major and most economic source of energy available on the market. However, diets for carnivorous fish, such as salmonids, contain high levels of proteins mainly in the form of fish meal, an expensive and increasingly scarce raw material. Several works have been carried out over the past decade to evaluate the effects of incorporation of carbohydrates in the diets of salmonids (Bergot, 1979; Pieper and Pfeffer, 1979; Hilton and Atkinson, 1982; Spannhof and Plantikow, 1983; Kaushik and Oliva Teles, 1985; Hilton et al, 1987; Kaushik et al, 1989).

Carbohydrates represent the major and common source of energy in diets of higher animals usually provided by the starch content of cereals which enable optimization of formulating costs (Hilton et al, 1987). However, some controversy persists as regards the optimum level of inclusion of carbohydrates. Bergot and Breque (1983) and more recently Kaushik and Oliva Teles (1985) and Kaushik et al (1989) reported that technological, hydrothermic treatment of crude starch would increase energy availability and the efficiency of protein utilization by salmonids.

Triticale, a wheat $x$ rye hybrid, is harvested in many regions of the world (Hadjipanayiotou et al, 1985) in order to associate the productive capacity of wheat with the resistance of rye. Despite the high production potential together with its lower cost, the use of triticale for human consumption is still confronted by consumer reluctance. Nonetheless, triticale has been successfully incorporated in feeds for broilers and pigs, being considered 1 of the cheapest carbohydrate sources and a good substitute for corn and wheat middlings in animal diets without any adverse effects on growth and feed efficiency (Bragg and Sharby, 1970; Fernandez and MacGinnis, 1974; Gerry, 1975; Bixler et al, 1986).

The main purpose of this work was to evaluate the effects of incorporation of triticale in rainbow trout diets and also to determine the optimum dietary inclusion levels.

\section{MATERIAL AND METHODS}

\section{Diets}

Six experimental diets were formulated to incorporate different levels of crude or precooked triticale (Clercal, hexaploid variety, a soft-wheat $x$ rye hybrid, number of chromosomes $=42$ ). Three diets contained crude triticale at 10,20 and $30 \%$ of dry matter (diets $\mathrm{T}_{10}, \mathrm{~T}_{20}$ and $\mathrm{T}_{30}$, respectively) and 2 other experimental diets contained precooked triticale $\left(15 \mathrm{~min}\right.$ at $110^{\circ} \mathrm{C}$ in an autoclave) at 20 and $30 \%$ levels (diets $\mathrm{CT}_{20}$ and $\mathrm{CT}_{30}$, respectively). $A$ control diet (T) was also formulated, based on fish meal as the only protein source and at an isoproteic (crude protein: $43 \% \mathrm{DM}$ ) and isoenergetic (gross energy: $20 \mathrm{~kJ} / \mathrm{g} \mathrm{DM}$ ) level common to all diets. The above 6 diets were tested in duplicate. In order to examine experimental conditions, 1 batch of fish was fed a commercial diet (diet C). The composition of the diets is reported in table I. The amino acid composition of the experimental diets is provided in table II.

\section{Growth studies}

325 under-yearling rainbow trout (Salmo gairdnerii), with a mean body weight of $102 \pm 2 \mathrm{~g}$, obtained from the Portuguese Aquaculture Services, were randomly divided into 13 equal groups and placed into fiberglass tanks of $400 \mathrm{I}$ capacity receiving a water flow rate of $20 \mathrm{l} / \mathrm{min}$. The trials were conducted at the experimental farm station of Tràs-os-Montes University, Portugal.

The water was saturated with dissolved oxygen and the temperature ranged between 15- 
Table I. Formulation and chemical composition of the diets. ${ }^{1}$ NRC, $1981 ;{ }^{2}$ calcium lignosulphite; ${ }^{*}$ precooked triticale $\left(110^{\circ} \mathrm{C}-15 \mathrm{~min}\right) ; \mathrm{nd}=$ not determined.

\begin{tabular}{lccccccc}
\hline $\begin{array}{l}\text { Ingredients } \\
\text { (\% DM) }\end{array}$ & Control & \multicolumn{7}{c}{ Diets } & & & \\
& & $T_{10}$ & $T_{20}$ & $T_{30}$ & $C T_{20}$ & $C T_{30}$ & \\
\hline Fish meal & 62 & 60 & 59 & 58 & 59 & 58 & \\
Dextrin & 30 & 22 & 13 & 4 & 13 & 4 & \\
Triticale & - & 10 & 20 & 30 & $20^{*}$ & $30^{*}$ & \\
Cod liver oil & 6 & 6 & 6 & 6 & 6 & 6 & \\
Min vit premix & 1 & 1 & 1 & 1 & 1 & 1 & \\
Binder 2 & 1 & 1 & 1 & 1 & 1 & 1 & \\
& & & & & & & \\
Chemical composition & Control & $T_{10}$ & $T_{20}$ & $T_{30}$ & $C T_{20}$ & $C T_{30}$ & Commercial \\
& & & & & & & \\
Dry matter (DM) & 92.2 & 93.2 & 93.0 & 92.3 & 93.8 & 94.9 & 88.9 \\
Protein (N x 6.25) (\% DM) & 42.7 & 42.6 & 42.4 & 42.8 & 42.6 & 42.9 & 42.6 \\
Fat (\% DM) & 10.1 & 11.1 & 11.1 & 11.8 & 11.9 & 11.9 & 10.2 \\
Starch (\% DM) & 14.4 & 15.0 & 16.3 & 17.2 & 17.4 & 17.9 & nd \\
Gross energy (kJ/g DM) & 20.6 & 20.5 & 20.6 & 20.6 & 20.7 & 21.1 & 20.1 \\
Ash (\% DM) & 12.2 & 12.1 & 12.8 & 12.2 & 12.4 & 12.4 & 13.8 \\
& & & & & & & \\
\hline
\end{tabular}

$17^{\circ} \mathrm{C}$ during the trial. After a week's adaptation period, fish were fed the experimental diets for 8 wks, twice a d, morning and afternoon (10 am and $5 \mathrm{pm}$ ). Diets were distributed at a rate of $2 \%$ of body weight per day. All fish were weighed every 2 wks and the feed intake levels were adjusted at such weighings. Final body weights of all fish were also recorded at the end of the $8 \mathrm{wk}$ growth trial. Ten fish were removed from an initial group and from each tank at the end of the trial and the chemical composition of eviscerated and non-eviscerated animals was determined.

\section{Digestibility}

Apparent digestibility coefficients (ADC) were determined using the indirect method with diets containing $1 \%$ of $\mathrm{Cr}_{2} \mathrm{O}_{3}$. Twenty fishes per tank (4 tanks per treatment) were adapted to the respective experimental diets and tanks and the faecal samples were collected using the apparatus developed by INRA (Choubert et al, 1982: cylindrical tanks of $60 \mathrm{I}$ capacity with a flow rate of $5 \mathrm{l} / \mathrm{min}$ ). For each diet, faecal samples were collected from the 4 groups of fish over $7 \mathrm{~d}$ and frozen daily. After freeze-drying, the faeces were analyzed for chromic oxide, protein, starch and energy contents.

\section{Blood metabolites}

After the growth trial, 6 groups of 25 fishes were fed the experimental diets in the usual manner for $4 \mathrm{~d}$. Another group were fasted for $4 \mathrm{~d}$. On the 5 th $d$, a single meal was offered at 9 am and individual blood samples were collected with heparinized syringes from the caudal vessel of 3 anesthetized (ethylene glyco monophenyl ether $1: 2500$ ) fishes from each group, including fasted fish at different intervals after the meal $(0,3,6$, 9,12 and $24 \mathrm{~h}$ ). The blood samples were then centrifuged ( $3000 \mathrm{rpm}, 20 \mathrm{~min}$ ) for separation of plasma and stored frozen before analysis of glucose and total free amino acid concentrations. 
Table II. Amino acid composition of experimental diets $(\mathrm{g} / 16 \mathrm{~g} \mathrm{~N})$ along with the EAA requirement values for salmonids (NRC, 1981). " In the absence of cystine; ${ }^{*}$ Phenylalanine + tyrosine.

\begin{tabular}{|c|c|c|c|c|c|c|c|}
\hline \multicolumn{8}{|c|}{ Diets } \\
\hline & $T$ & $T_{10}$ & $T_{20}$ & $T_{30}$ & $C T_{20}$ & $C T_{30}$ & EAA Needs \\
\hline Asp & 9.53 & 9.38 & 9.20 & 8.86 & 9.19 & 9.20 & \\
\hline Thr & 4.17 & 4.24 & 4.21 & 4.07 & 4.21 & 4.53 & \\
\hline Ser & 3.97 & 4.01 & 4.16 & 3.93 & 4.06 & 3.90 & \\
\hline Glu & 13.43 & 13.97 & 13.98 & 14.91 & 14.65 & 15.07 & \\
\hline Pro & 4.20 & 4.71 & 4.08 & 5.06 & 4.92 & 5.17 & \\
\hline Gly & 6.68 & 6.24 & 6.46 & 6.16 & 6.41 & 6.06 & \\
\hline Ala & 6.07 & 6.02 & 5.96 & 5.80 & 5.91 & 5.96 & \\
\hline Cys & 0.71 & 0.63 & 0.52 & 0.74 & 0.75 & 0.55 & \\
\hline Val & 5.26 & 5.32 & 5.15 & 5.25 & 5.31 & 5.38 & 3.20 \\
\hline Met & 2.68 & 2.86 & 2.67 & 2.70 & 2.71 & 2.82 & $4.00^{\star}$ \\
\hline $\mathrm{He}$ & 4.35 & 4.46 & 4.21 & 4.35 & 4.39 & 4.56 & 2.20 \\
\hline Leu & 7.31 & 7.50 & 7.24 & 7.26 & 7.34 & 7.48 & 3.90 \\
\hline$\overline{T y r}$ & 3.24 & 3.33 & 3.22 & 3.00 & 3.43 & 3.37 & \\
\hline Phe & 4.05 & 4.09 & 4.00 & 3.93 & 4.12 & 4.19 & $5.10^{* *}$ \\
\hline His & 2.50 & 2.48 & 4.31 & 2.45 & 2.54 & 2.64 & 1.80 \\
\hline Lys & 7.56 & 7.55 & 7.21 & 7.15 & 7.40 & 7.67 & 5.00 \\
\hline Arg & 6.50 & 6.42 & 6.43 & 6.66 & 6.47 & 6.35 & 6.00 \\
\hline
\end{tabular}

\section{Analytical methods}

Proximate analysis of diet, carcasses and faeces were made following the usual procedures: dry matter after drying in an oven at $104^{\circ} \mathrm{C}$ for $24 \mathrm{~h}$; ash by incineration at $550^{\circ} \mathrm{C}$ for $12 \mathrm{~h}$; protein $(\mathrm{N} \times 6.25)$ by Kjeldahl method after acid digestion; energy in an adiabatic bomb calorimeter (Parr); diet and carcass fat after extraction by the Soxhlet method; starch in the diets and faeces by the enzymatic method (Thivend et al, 1972) using glucoamylase and glucose oxidase; chromic oxide in diet and faeces according to Bolin et al (1952). Dietary amino acid analyses were made after acid hydrolysis $(\mathrm{HCl} 6 \mathrm{~N}$, $110^{\circ} \mathrm{C}, 24 \mathrm{~h}$ ) of samples and ion-exchange chromatography.

Total plasma free amino acids (as meq glycine equivalents) released by ninhydrin reaction (Spies, 1957) and glucose were measured enzymatically (Sigma Kit, No 510). Statistical analyses (analyses of variance followed by Duncan's multiple range test) were made following procedures outlined by Snedecor and Cochran (1956).

\section{RESULTS}

\section{Growth performance and food utilization}

Reported in table III are the results on growth performance and nutrient utilization efficiencies. Live body weight gain was significantly higher $(P<0.01)$ in all experimental batches than in fish fed the commercial diet. Within the experimental groups, the best results were observed in fish fed high levels of cooked triticale $\left(\mathrm{CT}_{30}\right)$ as well as in those fed the diet containing the lowest level of native triticale $\left(T_{10}\right)$. A significant decrease in weight gain $(P<0.01)$ was observed in fish fed diets containing 20 and $30 \%$ of untreated triticale (diets $\mathrm{T}_{20}$ and $\mathrm{T}_{30}$ ). Feed: gain (FGR $=$ dry feed intake/live weight gain) and protein efficiency ratios (PER = live weight 
Table III. Growth performance and nutrient utilization efficiencies in rainbow trout fed different levels of native and cooked triticale ${ }^{1}$. (1) Figures with different superscripts are significantly different from each other $(P<0.05)$. (2) Feed intake/weight gain. (3) Protein efficiency ratio = weight gain/protein intake. (4) Specific growth rate $=100 \times((\ln w f-\ln$ wi)/t) where wi and wf are initial and final weights and $t$ the duration in days of the trial. (5) Rentention as \% of dietary intake.

\begin{tabular}{|c|c|c|c|c|c|c|c|}
\hline Diets & $T$ & $T_{10}$ & $T_{20}$ & $T_{30}$ & $C T_{20}$ & $C T_{30}$ & $C$ \\
\hline Initial mean weight $(\mathrm{g})$ & $100.7^{a}$ & $102.7^{a}$ & $100.8^{a}$ & $101.4^{\mathrm{a}}$ & $99.9^{\mathrm{a}}$ & $99.2^{\mathrm{a}}$ & $104.1^{\mathrm{a}}$ \\
\hline Final mean weight $(g)$ & 220.2 & 226.0 & 213.3 & 215.4 & 217.1 & 222.9 & 189.9 \\
\hline Weight gain (g) & $119.5^{a}$ & $123.3^{a}$ & $112.5^{\mathrm{b}}$ & $114.0^{\mathrm{b}}$ & $117.2^{a}$ & $123.7^{a}$ & 85.8 \\
\hline Feed: Gain ratio 2 & $1.32^{\mathrm{ab}}$ & $1.22^{b}$ & $1.29^{\mathrm{ab}}$ & $1.44^{b}$ & $1.26^{\mathrm{ab}}$ & $1.19^{a}$ & 1.48 \\
\hline $\mathrm{PER}^{3}$ & $1.78^{a}$ & $1.79^{a}$ & $1.70^{\mathrm{a}}$ & $1.50^{\circ}$ & $1.75^{\mathrm{a}}$ & $1.84^{a}$ & 1.41 \\
\hline $\mathrm{SGR}^{4}$ & 1.50 & 1.52 & 1.44 & 1.44 & 1.50 & 1.55 & 1.15 \\
\hline Protein retention $(\%)^{5}$ & $38.6^{a}$ & $38.3^{a}$ & $35.9^{b c}$ & $32.0^{c}$ & $38.2^{\mathrm{a}}$ & $37.8^{a b}$ & 38.4 \\
\hline Energy retention (\%) & $42.4^{a}$ & $40.1^{a}$ & $39.7^{a}$ & $35.2^{b}$ & $40.4^{a}$ & $41.2^{a}$ & 36.5 \\
\hline
\end{tabular}

gain/protein intake) were significantly affected in trout fed diets containing $30 \%$ of native triticale.

Protein and energy retention efficiencies were also variably affected by the dietary treatments. In those fish fed cooked triticale containing diets, both energy and protein retention efficiencies were comparable to that observed for fish fed the control diet. Inclusion of uncooked triticale at above $20 \%$ in the diet (diets $T_{20}$ and $T_{30}$ ) led to a decrease in protein retention efficiency whereas energy retention was significantly $(P<0.01)$ reduced in those fish fed diet $\mathrm{T}_{30}$.

\section{Carcass composition}

The hepatosomatic index (liver wt/live body wt $\times 100$ ) was lower in rainbow trout fed diets $T_{20}$ and $T_{30}$ with high levels of incorporation of native triticale (table IV).
The protein, fat and energy contents of whole and eviscerated fishes were little affected by dietary treatments.

\section{Apparent digestibility coefficients (ADC)}

ADC values for dry matter were significantly lower $(P<0.01)$ for diets $\mathrm{T}_{20}$ and $\mathrm{T}_{30}$ than for the other experimental diets but were comparable to that of the commercial diet (table V). These differences were also reflected in the digestibility of energy of the different diets. ADC values for starch in diets containing precooked triticale $\left(\mathrm{CT}_{20}\right.$ and $\mathrm{CT}_{30}$ ) was above $90 \%$, significantly higher than those of diets with native triticale. Besides, there was a significant decline (from $78-54 \%$ ) in the digestibility of dietary starch with increasing levels of native triticale in the diets. No significant differences were observed in the ADC of pro- 
Table IV. Initial and final composition of rainbow trout fed different levels of native and cooked triticale ${ }^{1}$. 1 Figures with different superscripts are significantly different from each other $(P<0.01)$. ${ }^{2}$ Hepato somatic index $=w t$ of liver/live body woight $x 100$.

\begin{tabular}{|c|c|c|c|c|c|c|c|c|}
\hline & Initial & $T$ & $T_{10}$ & $T_{20}$ & $T_{30}$ & $C T_{20}$ & $C T_{30}$ & \\
\hline \multicolumn{9}{|l|}{ Whole fish } \\
\hline Dry matter (\%) & 27.7 & 32.4 & 33.3 & 32.2 & 33.3 & 33.2 & 32.5 & NS \\
\hline Protein (\% DM) & 55.3 & 54.3 & 52.6 & 53.4 & 52.1 & 53.2 & 52.4 & NS \\
\hline Fat $(\% \mathrm{DM})$ & 36.6 & 36.4 & 37.1 & 37.1 & 37.1 & 37.8 & 37.7 & NS \\
\hline Energy $(k J / g ~ D M)$ & 25.8 & 26.0 & 26.9 & 26.0 & 25.1 & 25.4 & 25.6 & NS \\
\hline $\mathrm{HSI}(\%)^{2}$ & 1.33 & $2.19^{\mathrm{a}}$ & $2.01^{\mathrm{a}}$ & $1.63^{b}$ & $1.69^{b}$ & $2.24^{a}$ & $2.14^{a}$ & $* *$ \\
\hline \multicolumn{9}{|l|}{ Eviscerated fish } \\
\hline Dry matter $(\%)$ & 23.1 & 30.3 & 29.8 & 30.1 & 29.9 & 31.6 & 31.7 & NS \\
\hline Protein (\% DM) & 61.6 & 61.3 & 59.7 & 59.2 & 59.0 & 57.6 & 58.7 & NS \\
\hline Fat (\% DM) & 29.8 & 29.1 & 31.3 & 32.9 & 31.5 & 33.5 & 32.8 & NS \\
\hline Energy (kJ/g DM) & 24.6 & 25.1 & 25.5 & 25.7 & 24.0 & 24.9 & 25.1 & NS \\
\hline \multicolumn{9}{|l|}{ Viscera } \\
\hline$\%$ body weight & 11.3 & 12.6 & 12.0 & 12.3 & 11.6 & 12.6 & 12.3 & NS \\
\hline Dry matter (\%) & 48.7 & 46.6 & 46.7 & 46.9 & 49.8 & 44.5 & 43.6 & NS \\
\hline
\end{tabular}

tein of the different experimental diets. On the basis of data on intake, digestibility and carcass composition, a tentative energy budget was made which is reported in table VI. It is clear that inclusion of cooked triticale improved energy retention per unit DM intake.

\section{Blood metabolites}

Post-prandial glucose levels in plasma presented slightly different patterns of changes depending on the dietary level and quality of triticale (table VII). The prefeeding level was reached by $24 \mathrm{~h}$ after

Table V. Apparent digestibility coefficients (ADC) of the test diets $(\%)^{1}$. (1) Figures with different superscripts are significantly different from each other $(P<0.05)$.

\begin{tabular}{llllllll}
\hline Diets & $T$ & $T_{10}$ & $T_{20}$ & $T_{30}$ & $C T_{20}$ & $C T_{30}$ & $C$ \\
\hline Dry matter & $73.9^{\mathrm{a}}$ & $72.3^{\mathrm{a}}$ & $64.5^{\mathrm{b}}$ & $62.7^{\mathrm{b}}$ & $74.0^{\mathrm{a}}$ & $75.3^{\mathrm{a}}$ & 62.5 \\
Protein & 85.7 & 86.3 & $84.4^{\mathrm{a}}$ & $84.8^{\mathrm{a}}$ & $87.7^{\mathrm{a}}$ & $89.2^{\mathrm{a}}$ & 85.8 \\
Energy & $85.1^{\mathrm{a}}$ & $83.4^{\mathrm{a}}$ & $77.1^{\mathrm{b}}$ & $75.2^{\mathrm{b}}$ & $85.2^{\mathrm{a}}$ & $86.7^{\mathrm{a}}$ & 79.2 \\
Starch & $94.3^{\mathrm{a}}$ & $77.9^{\mathrm{b}}$ & $58.2^{\mathrm{c}}$ & $54.2^{\mathrm{d}}$ & $90.9^{\mathrm{a}}$ & $93.6^{\mathrm{ae}}$ & - \\
\hline
\end{tabular}


Table VI. Gross (GE), digestible (DE), metabolizable (ME) and net energy (NE) values of the diets ( $\mathrm{kJ} / \mathrm{g} \mathrm{DM}$ intake). $\mathrm{GE}=$ Gross energy; $\mathrm{DE}=$ Digestible energy; $\mathrm{ME}$ (Metabolizable energy) = DE NFEL; NFEL (Non-fecal energy loss) = NFNL $\times 25 \mathrm{~kJ} / \mathrm{gN}$ (as per Elliott and Davidson, 1975) where NFNL (non-fecal nitrogen loss) : Digestible $N-$ Retained N; NE (Net energy) = ME - HiE where HiE (heat increament of feeding) $=$ Digestible $\mathrm{N} \times 28 \mathrm{~kJ} / \mathrm{gN}$ (as per Cho et al, 1982); RE = Retained energy.

\begin{tabular}{|c|c|c|c|c|c|c|}
\hline & $T$ & $T_{10}$ & $T_{20}$ & $T_{30}$ & $C T_{20}$ & $C T_{30}$ \\
\hline GE & 20.6 & 20.5 & 20.6 & 20.6 & 20.7 & 20.9 \\
\hline $\mathrm{DE}$ & 17.5 & 17.1 & 15.9 & 15.5 & 17.6 & 18.1 \\
\hline ME & 16.7 & 16.2 & 15.0 & 14.5 & 16.7 & 17.1 \\
\hline NE & 14.9 & 14.5 & 13.3 & 12.8 & 15.0 & 15.4 \\
\hline RE & 8.7 & 8.2 & 8.2 & 7.2 & 8.4 & 8.6 \\
\hline
\end{tabular}

meals only in those trout fed the diet containing $10 \%$ triticale and to a certain extent in those fed the control diet (diet T). In trout fed higher levels of triticale (both native and cooked), plasma glucose levels were relatively higher even $24 \mathrm{~h}$ after the meal.

The concentration of free amino acids in plasma increased after feeding with peak levels between 6 and $9 \mathrm{~h}$ after meal in all groups. However, only in those fish fed cooked triticale (batches $\mathrm{CT}_{20}$ and $\mathrm{CT}_{30}$ ) was there a definite diurnal pattern as was the case $24 \mathrm{~h}$ after the meal, the levels were comparable to the pre-feeding levels. The amplitude of changes were not different between fish fed the different experimental diets (table VIII).

Table VII. Post-prandial development of plasma glucose in trout fed different levels of native and cooked triticale ${ }^{1}$ (in $\mathrm{mg} / 100 \mathrm{ml}$ ). (1) Means with standar errors $(n=3)$ are given. Zero $\mathrm{h}$ corresponds to $9 \mathrm{am}$. Fasted control value $=67.7 \pm 7.0 \mathrm{mg} / 100 \mathrm{ml}$.

\begin{tabular}{rrrrrrr}
\hline $\begin{array}{c}\text { Hours } \\
\text { after meal }\end{array}$ & $T$ & \multicolumn{1}{c}{$T_{10}$} & \multicolumn{1}{c}{$T_{20}$} & \multicolumn{1}{c}{$T_{30}$} & \multicolumn{1}{c}{$C T_{20}$} & \multicolumn{1}{c}{$C T_{30}$} \\
\hline & & & & & & \\
\hline 0 & $77.3 \pm 21.4$ & $89.3 \pm 12.5$ & $93.6 \pm 6.6$ & $90.7 \pm 9.6$ & $69.3 \pm 27.6$ & $69.5 \pm 9.8$ \\
3 & $139.0 \pm 12.8$ & $94.5 \pm 5.4$ & $133.0 \pm 11.9$ & $125.2 \pm 9.4$ & $99.5 \pm 12.8$ & $99.2 \pm 0.3$ \\
6 & $143.8 \pm 10.9$ & $133.4 \pm 12.6$ & $143.8 \pm 27.4$ & $123.0 \pm 18.7$ & $133.4 \pm 21.7$ & $112.1 \pm 31.3$ \\
9 & $109.4 \pm 5.1$ & $138.9 \pm 20.1$ & $133.9 \pm 25.1$ & $140.4 \pm 18.9$ & $169.9 \pm 12.1$ & $160.6 \pm 10.5$ \\
12 & $162.4 \pm 3.5$ & $156.2 \pm 11.6$ & $143.4 \pm 20.7$ & $168.1 \pm 25.0$ & $178.1 \pm 42.1$ & $150.5 \pm 16.9$ \\
24 & $112.4 \pm 11.3$ & $89.5 \pm 5.1$ & $160.0 \pm 18.9$ & $154.6 \pm 25.0$ & $169.8 \pm 8.6$ & $163.6 \pm 8.9$ \\
\hline
\end{tabular}


Table VIII. Post-prandial development of plasma tree amino acids in trout fed different levels of native and cooked triticale ${ }^{1}$ (in mM equiv/glycine). ${ }^{1}$ Means with standard errors $(n=3)$ are given. Zero hour corresponds to 9 am.

\begin{tabular}{ccccccc}
\hline $\begin{array}{c}\text { Hours after } \\
\text { meal }\end{array}$ & $T$ & $T_{10}$ & $T_{20}$ & $T_{30}$ & $C T_{20}$ & $C T_{30}$ \\
\hline & & & & & & \\
\hline 0 & $1.24 \pm 0.3$ & $2.35 \pm 0.7$ & $2.38 \pm 1.1$ & $1.99 \pm 0.7$ & $1.32 \pm 0.5$ & $1.32 \pm 0.2$ \\
3 & $2.88 \pm 0.6$ & $2.63 \pm 0.5$ & $3.30 \pm 0.1$ & $3.82 \pm 0.5$ & $4.03 \pm 1.1$ & $3.73 \pm 1.0$ \\
6 & $5.43 \pm 0.7$ & $4.27 \pm 0.6$ & $5.04 \pm 0.2$ & $5.65 \pm 1.1$ & $5.19 \pm 0.5$ & $5.37 \pm 1.5$ \\
9 & $4.16 \pm 0.5$ & $4.73 \pm 1.1$ & $7.85 \pm 0.8$ & $3.14 \pm 0.7$ & $5.03 \pm 2.0$ & $2.99 \pm 0.9$ \\
12 & $3.78 \pm 0.7$ & $4.19 \pm 0.5$ & $3.99 \pm 1.5$ & $3.61 \pm 0.1$ & $4.1 \pm 1.7$ & $3.92 \pm 1.6$ \\
24 & $3.98 \pm 0.2$ & $4.61 \pm 0.8$ & $3.79 \pm 0.1$ & $4.77 \pm 1.1$ & $1.71 \pm 0.1$ & $1.87 \pm 0.5$ \\
& & & & & & \\
\hline
\end{tabular}

\section{DISCUSSION}

The nutritive value of triticale for higher animals has been studied to a great extent (Bourdon and Perez, 1982; Perez and Bourdon, 1986). One of the interesting features of this cereal for terrestrial animal feeds is its relatively high lysine content (Davies, 1989). In the present trial with rainbow trout, the protein and amino acid composition of triticale only had minor significance since fishmeal was the major source of these essential nutrients. Besides, as can be seen in table II, in all the experimental diets, requirements for all essential amino acids of salmonids were met.

Incorporation of up to $30 \%$ of cereals in rainbow trout diets did not appear to exert any adverse effects on growth performance provided the cereal was submitted to a thermal treatment. In fact, inclusion of 20 and $30 \%$ of native triticale in trout diets led to some negative effects on selected growth parameters, in accordance with many previous observations on the effects of crude starch incorporation in salmonid diets (Edwards et al, 1977; Refstie and Austreng, 1981; Hilton et al, 1987). On the other hand, with diets containing cooked triticale, growth of rainbow trout was comparable to those fed the control diet, supporting similar results obtained earlier by Bergot and Breque (1983) and Kaushik et al (1989).

The changes in hepatosomatic indices (HSI) were comparable to those observed by Refstie and Austreng (1981) in rainbow trout fed high carbohydrate diets. Thermal treatment of cereals made more digestible energy available and led to an increase in the HSI of rainbow trout with values comparable to those observed in fish fed the control diet containing dextrin. Inclusion of native triticale decreased the digestible energy level and consequently the hepatosomatic indices were also affected by changes in the availability of starch. Dressed weights were not found to be affected by dietary starch levels in rainbow trout by Bergot (1979), but our results on viscero-somatic indices were slightly higher than those observed by the latter author. The changes in dry matter content of viscera and in eviscerated fish can explain the differences observed in protein and fat contents of groups fed diets containing more digestible carbohydrates; the same 
type of variation was observed by Bergot (1979).

The decrease in the ADC of dry matter with increasing levels of inclusion of native triticale corresponds to an increase in the amount of crude starch provided by the cereal. It is known that the digestibility of starch decreases with the level of crude starch inclusion in trout diets (Singh and Nose, 1967; Rychly and Spannhof, 1979). This leads to a direct change in the amount of digestible energy made available to rainbow trout as has already been demonstrated by several previous works (Rychly and Spannhof, 1979; Hilton et al, 1982; Spannhof and Plantikow, 1983). The positive effect of starch gelatinization was clearly demonstrated with the higher digestibility coefficients observed (> 90\%) for diets containing cooked triticale with data comparable to diets containing dextrin. The DE values were then clearly improved when triticale was cooked. Protein digestibility is little affected by carbohydrate content of the diets (Reftsie and Austreng, 1981) and this was also evident from our results. The better protein retention efficiencies observed in fish fed diets containing cooked triticale can be explained by a decrease in nitrogen excretion in response to an increase in dietary non-protein digestible energy (Kaushik and Oliva Teles, 1985). This improvement cannot be explained by any depression in feed intake with diets high in digestible carbohydrates, as the level of feed intake was maintained constant in all batches during the experiment. No evidence is obtained for the probably high alpha-amylase activity suggested in triticale by Falisse (1980).

On the basis of results obtained on the ADC of different experimental diets, we can estimate the dry matter digestibility of native and cooked triticale to be 40 and $74 \%$ respectively, but more specific work will be necessary to confirm these values.
The post-prandial development of plasma glucose concentrations is known to be dependent upon the source and level of carbohydrates (Bergot, 1979; Kaushik and Oliva-Teles, 1985). These studies have shown that in fish fed diets containing crude starch, there is generally a low increase in the postprandial glycemia levels than in those fed pre-treated starch or glucose. In the present study, although the basal level found in fasted fish (68 $\mathrm{mg}$ glucose/100 ml) was comparable to earlier observations by Kaushik and Oliva-Teles (1985), the frequency of blood sampling was not adequate enough to demonstrate clear patterns of changes in fed fish as shown in earlier studies. Besides, the method involved in the analysis of plasma glucose was also different from the one used in the above cited works. However, sustained peak levels were only observed in those fish fed cooked triticale in comparison to those fed native triticale.

The post-prandial increase in plasma free amino acid levels depends to a large extent on the dietary protein intake. However, in some studies, it was shown that the post-prandial patterns could be affected by the quality of dietary starch. Kaushik and Oliva-Teles (1985) found a slower rate of increase in the free amino acid levels in fish fed crude starch in comparison to those fed gelatinized starch. Increased glycemia is also known to provoke a decrease in free amino acid levels in plasma (Palmer and Ryman, 1972) and our results do show such a decrease in plasma free amino acids in fish fed high levels of cooked triticale. It is worth noting that the post-prandial pattern of changes in plasma total free amino acid levels is affected by the quality of triticale included in the diet. Whether such differences in the overall patterns also reflect changes in individual. amino acid levels requires further study. 


\section{CONCLUSION}

Triticale appears to be a promising ingredient for inclusion in rainbow trout diets provided it is subject to preliminary thermal treatment in order to increase the level of available energy.

\section{REFERENCES}

Bergot F (1979) Carbohydrates in rainbow trout diets: effects of the level and source of carbohydrates and the number of meals on growth and body composition. Aquaculture $18,157-167$

Bergot F, Breque J (1983) Digestibility of starch by rainbow trout: effects of the physical state of starch and of the intake level. Aquaculture 34, 203-212

Bixler E, Schaible PS, Bandemer S (1986) Preliminary studies on the nutritive value of triticale as chicken feed. $Q$ Bull Michigan Agric Exp Sta, Michigan State University 50 (3), 276

Bolin DW, King RP, Klosterman WW (1952) A simplified method for the determination of chromic oxide $\left(\mathrm{Cr}_{2} \mathrm{O}_{3}\right)$ when used as an inert substance. Science 16 (3023), 634-635

Bourdon D, Perez JM (1982) Valeur nutritive du triticale pour le porc : comparaison avec le blé, le seigle et un maïs riche en protéines. Journées Rech Porcine en France, INRA, ITP ed, Paris, 14, 223-230

Bragg DB, Sharby TF (1970) Nutritive value of triticale for broiler chick diets. Poultry Sci 49, 1022-1027

Cho CY, Slinger SJ, Baley HS (1982) Bioenergetics of salmonid fishes: energy intake, expenditure and productivity. Comp Biochem Physiol 73B, 25-41

Choubert G, De la Noüe J, Luquet P (1982) Digestibility in fish: improved device for the automatic collection of feces. Aquaculture 29, 185-189
Davies RL (1989) Triticale's potential as a source of amino acids for pigs. Anim Prod Australia 20, 140-143

Elliot JM, Davison W (1975) Energy equivalents of oxygen consumption in animal energetics. Oecologia 19, 195-201

Edwards DJ, Austreng E, Risa S, Gjedrem T (1977) Carbohydrate in rainbow trout diets. I. Growth of fish of different families fed diets containing different proportions of carbohydrate. Aquaculture 11, 31-38

Falisse A (1980) La Culture du Triticale. Ministère de l'Agriculture, Manhattan Center, Office Tower, 1210 Brussels

Fernandez R, McGinnis J (1974) Nutritive value of triticale for young chicks and effect of different amino acid supplements on growth. Poultry Sci 53, 47-53

Gerry RW (1975) Triticale in broiler rations. Feedstuffs 47 (49) 24-25

Hilton JW, Atkinson JL (1982) Response of rainbow trout (Salmo gairdneri) to increased levels of available carbohydrate in practical trout diets. Br J Nutr 47, 597-607

Hilton JW, Atkinson JL, Slinger S (1982) Maximum tolerable level, digestion, and metabolism of D-glucose (cerelose) in rainbow trout (Salmo gairdneri) reared on a practical trout diet. Can J Fish Aquat Sci 39, 1229-1234

Hilton JW, Alkinson JL, Slinger SJ (1987) Evaluation of net energy value of glucose (cerelose) and maize starch in diets for rainbow trout (Salmo gairdneri). Br J Nutr 58, 453-461

Hadjipanayiotou S, Economides S, Georghiades $E$ (1985) Nutritive value of triticale and barley grain and straw. Agric Res Inst, Nicosia, Cyprus

Kaushik SJ, Oliva Teles A (1985) Effect of digestible energy on nitrogen and energy balance in rainbow trout. Aquaculture 50, 89101

Kaushik S, Luquet P, Blanc D, Paba A (1989) Studies on the nutrition of siberian sturgeon, Acipenser baeri. I. Utilization of digestible carbohydrates by sturgeon. Aquaculture 76, 97-107 
Kaushik SJ, Medale F, Fauconneau B, Blanc D (1989) Effect of digestible carbohydrates on protein energy utilization and on glucose metabolism in rainbow trout (Salmo gairdneri). Aquaculture 79, 63-74

NRC (National Research Council) (1981) Nutrient Requirements of Domestic Animals. Nutrient Requirements of Coldwater Fishes. National Academy of Sciences, Washington DC, USA, $233 \mathrm{pp}$

Palmer TN, Ryman BE (1972) Studies on oral glucose intolerance in fish. J Fish Biol 4, 311. 319

Perez JM, Bourdon D (1986) Valeur énergétique et azotée des triticales français : synthèse des résultats. Journées Rech Porcine, INRA, ITP ed, Paris, 18, 79-82

Pieper A, Pfeffer E (1980) Studies on the effect of increasing proportions of sucrose or gelatinized maize starch in diets for rainbow trout (Salmo gairdneri, R) on the utilization of dietary energy and protein. Aquaculture 20, 333342

Refstie T, Austreng E (1981) Carbohydrate in rainbow trout diets. III. Growth and chemical composition of fish from different families fed four levels of carbohydrate in the diet. Aquaculture 25, 35-49

Rychly J, Spannhof L (1979) Nitrogen balance in trout. I. Digestibility of diets containing varying levels of protein and carbohydrate. Aquaculture 16, 39-46

Singh RP, Nose T (1967) Digestibility of carbohydrates in young rainbow trout. Bull Freshwat Fish Res Lab 17, 21-25

Snedecor GW, Cochran WG (1956) Statistical Methods. lowa State University Press, Ames, IA, 534 pp

Spannhof L, Plantikow H (1983) Studies on carbohydrate digestion in rainbow trout. Aquaculture 30, 95-108

Spies JR (1957) Colorimetric procedures for amino acids. In: Methods in Enzymology (Colowick SP, Kaplan NO, eds) Academic Press, New York, 3, 467-477

Thivend P, Mercier C, Guilbot A (1972) Determination of starch with glucoamylase. In: Methods in Carbohydrate Chemistry (Whistler RL, Bemiller JN, eds) Academic Press, New York, 6, 100-105 